\title{
Evaluation of P - POSSUM Scoring System in Patients Undergoing Emergency Laparotomy
}

\author{
Manoj Kumar Jha', Yahun Chandra Sibakoti² and Harihar Devkota ${ }^{3}$
}

1: Department of Surgery, Shree Birendra Hospital, Chhauni, Kathmandu, Nepal.

2: Department of Surgery, National Academy of Medical Sciences, Kathmandu, Nepal.

3: Karnali Academy of Health Sciences, Jumla, Nepal.

\begin{abstract}
Introduction: The Physiological and Operative Severity Score for the enumeration of Mortality and morbidity (POSSUM) and its modification the Portsmouth POSSUM (P-POSSUM), have been proposed as a method for standardizing patient data so that direct comparisons can be made despite differing patterns of referral and population. In this prospective study, the validity of P-POSSUM was tested in patients undergoing emergency laparotomy and the risk factors for low outcome were noted.

Methods: This is the Prospective Study and was conducted in Department of surgery of a tertiary level hospital. The study period was from April 2014 - April 2015 for one year. Patients admitted under department of general surgery scheduled to undergo emergency laparotomy were included and scored according to their physiological and operative findings using a proforma sheet. Physiological scoring was performed just before surgery and operative scoring was carried out intra-operatively. Patients were followed-up for the first 30 days postoperative period. The observed mortality rate was compared with the P-POSSUM predicted mortality rate. Data analysis was done using SPSS 20.

Results: A total of 60 patients who met the inclusion criteria were included in this study. On applying linear analysis, an observed to expected ratio of 1.18 was obtained, indicating a significant fit for predicting the post-operative adverse outcome. There was no significant difference between the observed and predicted mortality rates $\left(x^{2}=1.467,4 \mathrm{df}\right.$., $\left.\mathrm{P}=0.833\right)$. In all the risk factors studied, a positive correlation was found between deaths and higher POSSUM scores.

Conclusion: Portsmouth POSSUM scoring system serves as a good predictor of post-operative outcome in emergency laparotomy procedures.
\end{abstract}

Keywords: POSSUM; surgical scoring; mortality

Correspondence: Manoj Kumar Jha, Department of Surgery, Nepalese Army Institute of Health Sciences, Shree Birendra Hospital, Chhauni, Kathmandu, Nepal. Email: drmanojkjha@gmail.com

To cite this article: Jha MK, Sibakoti YC, Devkota H. Evaluation of P-POSSUM Scoring System in Patients Undergoing Emergency Laparotomy. Medical Journal of Shree Birendra Hospital. 2017;17(2): 28-36.

DOI: $\underline{\text { http://dx.doi.org/10.3126/mjsbh.v16i2.17714 }}$

\section{Conflict of Interest: None declared}

This work is licensed under creative common license: http://creativecommons.org/ licenses/by-nc-nd/4.0/ C Medical Journal of Shree Birendra Hospital 


\section{INTRODUCTION}

Comparing the influence on adverse outcome, we can assess the efficiency of that particular procedure and assess the quality of care provided to the patient.1,2 Risk scoring seeks to quantify a patient's risk of adverse outcome based on the severity of illness derived from data available at an early stage of the hospital stay. ${ }^{3,4}$ Scoring should cover all prospects of patient care and should be easy to use, fast, and comparable among different patient groups. The Physiological and Operative Severity Scoring system for the enUmeration of Morbidity and mortality (POSSUM) has been proposed as a risk adjusted scoring system to allow for direct comparison between the observed and expected adverse outcome rates.5,6 It has 12 physiological and 6 operative variables. Each factor is assigned scores depending upon the severity. ${ }^{5}$ The Portsmouth POSSUM (P-POSSUM) is a modification of the POSSUM scoring system, incorporating the same variables and grading system, but a different equation, which provides a better fit to the observed mortality rate, which is an important and objective measure of outcome. ${ }^{7,8}$

It has already found use in general $^{9}$, vascular ${ }^{10-13}$, colorectal $^{14-16}$, esophageal17,18 and laparoscopic ${ }^{19}$ procedures but the studies mostly involved patients in developed countries, where the patient characteristics, presentation and available resources differ from our setup. ${ }^{20}$ Hence, there is a need to test the validity of P-POSSUM scoring system in our population. This study was undertaken to assess the validity of P-POSSUM scoring system in patients undergoing emergency laparotomy in our setup because such studies have not been done in this part of world and, try to analyze the causes for poor outcome in these high-risk group.

\section{METHODS}

This was a prospective study conducted in a tertiary level referral hospital of Kathmandu, Nepal for a duration of one year from April 2014 - April 2015. Every case presenting for emergency laparotomy under general surgery for one-year period were included in this study after assessment of the inclusion criteria and cases were followed up for 30 days following the surgical procedure. Patients above 14 years of age, both males and females, who underwent emergency laparotomy were recruited for study. Patients unfit for general anesthesia, patients requiring cardiopulmonary resuscitation before surgery, mentally disabled patients; patient less than 14 years of age, patients requiring damage control surgery before definitive treatment and who cannot meet follow up criteria were excluded.

Informed written consent was taken prior to inclusion of the individuals into the study. The study protocol was approved by the local ethical clearance committee of the hospital. During hospitalization, relevant history was collected and appropriate investigations as deemed necessary were done using standard procedures. The patients were then scored depending on their physiological and the intra operative findings were noted using a proforma sheet and a final expected mortality rate was calculated.

During 30 days follow up period following the surgical procedure and complications if any, were noted depending upon the criteria as defined for POSSUM scoring system. Data obtained was entered in SPSS and analyzed using linear regression analysis and the $\mathrm{O}$ : $\mathrm{E}$ ratio was calculated to obtain expected mortality rate. Chisquare $(x 2)$ test to see the association between POSSUM score and poor outcome. Rate of increment in deaths for each risk factor was calculated based on the hypothesis that deaths were linearly related with the score for each of the studied risk factors and ' $t$ ' test was applied to validate this hypothesis. 
Physiological Score used for the study:-

\begin{tabular}{|c|c|c|c|c|}
\hline Parameters/ Score & 1 & 2 & 4 & 8 \\
\hline Age (Years) & $<60$ & $61-70$ & $>71$ & \\
\hline Chest X-Ray & $\begin{array}{l}\text { No Failure } \\
\text { Normal }\end{array}$ & $\begin{array}{l}\text { Diuretic, Digoxin, } \\
\text { antianginal or } \\
\text { antihypertensive } \\
\text { therapy } \\
\text {-- }\end{array}$ & $\begin{array}{l}\text { Peripheral edema, } \\
\text { Warfarin } \\
\text { Therapy } \\
\text { Borderline } \\
\text { Cardiomegaly }\end{array}$ & $\begin{array}{l}\text { Raised JVP } \\
\text { Cardiomegaly }\end{array}$ \\
\hline Respiratory History & $\begin{array}{l}\text { No Dyspnoea } \\
\text { Normal }\end{array}$ & $\begin{array}{l}\text { Dyspnoea on } \\
\text { Exertion } \\
\text { Mild COAD }\end{array}$ & $\begin{array}{l}\text { Limiting dyspnoea } \\
\text { (one } \\
\text { flight of stairs) } \\
\text { Moderate COAD }\end{array}$ & $\begin{array}{l}\text { Dyspnoea at } \\
\text { Rest (rate }>30 / \\
\text { min) } \\
\text { Fibrosis or } \\
\text { Consolidation }\end{array}$ \\
\hline $\begin{array}{l}\text { Blood pressure } \\
\text { (systolic)(mmHg) }\end{array}$ & $110-130$ & $\begin{array}{l}131-170 \text { or } \\
100-109\end{array}$ & $\begin{array}{l}>171 \text { or } \\
90-99\end{array}$ & $<89$ \\
\hline Pulse (beats/min) & $50-80$ & $\begin{array}{l}81-100 \\
40-49\end{array}$ & $101-120$ & $\begin{array}{l}>121 \\
<39\end{array}$ \\
\hline Glasgow coma Scale & 15 & $12-14$ & $9-11$ & $<8$ \\
\hline $\operatorname{Hemoglobin}(\mathrm{g} / \mathrm{dl})$ & $13-16$ & $11.5-12.9$ or $16.1-17.0$ & $\begin{array}{l}10.0-11.4 \text { or } \\
17.1-18.0\end{array}$ & $\geq 18.1$ \\
\hline $\begin{array}{l}\text { White cell count } \\
(\times 1012 / \mathrm{l})\end{array}$ & $4-10$ & $10.1-20$ or $3.1-4$ & $\geq 20.1$ or $\leq 3$ & \\
\hline Blood urea(mmol/l) & $\leq 7.5$ & $7.6-10$ & $10.1-15$ & $\geq 15.1$ \\
\hline Sodium (mmol/l) & $\geq 136$ & $131-135$ & $126-130$ & $\leq 125$ \\
\hline Potassium (mmol/l) & $3.5-5$ & $3.2-3.4$ or $5.1-5.3$ & $2.9-3.1$ or $5.4-5.9$ & $\leq 2.8$ or $\geq 6$ \\
\hline ECG & Normal & -- & $\begin{array}{l}\text { Atrial fibrillation } \\
\text { (rate 60-90) }\end{array}$ & $\begin{array}{l}\text { Any other } \\
\text { Changes }\end{array}$ \\
\hline
\end{tabular}

Operative severity score used for the study. Mortality is $($ Loge $[R / 1-R]=-9.065++(0.1692 x$ Physiological Score $)+(0.155 \times$ Operative Score $)$ Where $\mathrm{R}=$ risk of mortality. ${ }^{8)}$

\begin{tabular}{|l|l|l|l|l|}
\hline \multicolumn{2}{|c|}{1} & 2 & 4 & 8 \\
\hline Operative severity & Minor & Moderate & Major & Major Plus \\
\hline Multiple procedures & 0 & 1 & 2 & $>2$ \\
\hline Total blood loss (ml) & $<100$ & $101-500$ & $501-999$ & $>1000$ \\
\hline Peritoneal soiling & None & $\begin{array}{l}\text { Minor (serous } \\
\text { fluid) }\end{array}$ & Local pus & $\begin{array}{l}\text { Free bowel } \\
\text { content, pus or blood }\end{array}$ \\
\hline $\begin{array}{l}\text { Presence of } \\
\text { malignancy }\end{array}$ & None & Primary only & Nodal metastases & Distant metastases \\
\hline Mode of surgery & Elective & & $\begin{array}{l}\text { Emergency } \\
\text { resuscitation of }>2 \mathrm{~h} \\
\text { possible, } \\
\text { Operation }<24 \mathrm{~h} \\
\text { after admission }\end{array}$ & $\begin{array}{l}\text { Emergency } \\
\text { (immediate surgery }<2 \mathrm{~h} \\
\text { needed) }\end{array}$ \\
\hline
\end{tabular}


Table 1. Indications for emergency .laparotomy

\begin{tabular}{|l|r|r|}
\hline Indications & Frequency & $\%$ \\
\hline DU perforation & 19 & 31.7 \\
\hline Appendicular perforation & 10 & 16.7 \\
\hline Intestinal Obstruction & 9 & 15 \\
\hline Ileal perforation & 7 & 11.7 \\
\hline Jejunal Perforation & 7 & 11.7 \\
\hline Obstructed Hernia & 4 & 6.7 \\
\hline Others & 4 & 6.7 \\
\hline Total & 60 & 100 \\
\hline
\end{tabular}

Table 2. Complications

\begin{tabular}{|c|c|c|}
\hline Complications & $\%$ & Frequency \\
\hline Wound infection & 48.3 & 29 \\
\hline Chest infection & 26.7 & 16 \\
\hline Anastomotic leak & 6.7 & 4 \\
\hline Hypotension & 13.3 & 8 \\
\hline Respiratory failure & 8.3 & 5 \\
\hline Wound dehiscence & 20.0 & 12 \\
\hline Impaired renal function & 3.3 & 2 \\
\hline Septicemia & 6.7 & 4 \\
\hline UTI & 6.7 & 4 \\
\hline Cardiac failure & 8.3 & 5 \\
\hline Others & 3.3 & 2 \\
\hline None (no complications) & 40.0 & 24 \\
\hline
\end{tabular}

\section{RESULTS}

A total of 60 patients who met the inclusion criteria were included in this study. Out of which 54 (90\%) patients were male and $6(10 \%)$ patients were female. Age of the patient were ranges from 16-81 years. Among them 55 (91.7\%) were of $<=60$ years, two $(3.3 \%)$ of $61-70$ years and $3(5 \%)$ were of $>70$ years.
Among 60 patient undergoing emergency laparotomy, 19 patients were operated for duodenal ulcer perforation. Other indications were appendicular perforation, intestinal obstruction, ileal perforation, jejunal perforation and obstructed hernia in descending sequence. There was patient with ruptured hydatid cyst, traumatic bladder injury, Blunt abdominal trauma (BAT) with liver injury and with mesenteric ischemia each. (Table 1)

The post-operative complications noted during the 30 day follow up period are listed in (Table 2). Among 60 operated cases only 24 patients did not develop any complications in 30 days immediate post-operative period.

Comparison of observed and P-POSSUM predicted mortality rates was done using linear analysis as represented in (Table 3). An observed to expected ratio $(\mathrm{O}: \mathrm{E})$ of one was obtained and there was no significant difference between the predicted and observed outcome was noted $\left(\mathrm{x}^{2}=1.523\right.$, df $4, \mathrm{P}=$ $0.823)$.

We found positive rate of increment with all the risk factors studied but it was found to be statistically significant with respect to hemoglobin $(\mathrm{p}=0.001)$, WBC $(\mathrm{p}=0.002)$, Urea $(\mathrm{p}=0.001)$, sodium $(\mathrm{p}=0.019)$, potassium $(\mathrm{p}=0.030)$, peritoneal soiling $(\mathrm{p}=0.001)$ and Mode of surgery $(\mathrm{p}=0.001)$ (Table 4.).

\section{DISCUSSION}

In our institution, peritonitis due to hollow viscous perforation has become the leading cause of emergency laparotomies. In our study, we performed emergency laparotomy in 60 patients. Most of the surgeries were performed on patient with hollow viscus perforations (43 cases $71.66 \%$ ). In our study nine $(15 \%)$ patient were operated for intestinal obstruction and four patients with obstructed hernia. Gastro intestinal tract perforations can occur due to various causes, and 
Table 3. Comparison of observed and expected mortality rate. O: observed number of deaths, E: expected number of deaths, chi square $=1.523, \mathrm{df}=4, \mathrm{P}=0.823$

\begin{tabular}{|c|c|c|c|c|c|}
\hline $\begin{array}{l}\text { Predicted mortality } \\
\text { rate } \%\end{array}$ & No. of procedures & Mean predicted risk & 0 & $\mathbf{E}$ & O:E \\
\hline$<=11$ & 44 & 3.62 & 2 & 2 & 1.26 \\
\hline 11-19 & 11 & 15.21 & 1 & 2 & 0.60 \\
\hline 20-29 & 3 & 27.17 & 1 & 1 & 1.23 \\
\hline $30-39$ & 1 & 39.56 & 1 & 0 & 2.53 \\
\hline $60-69$ & 1 & 60.40 & 1 & 1 & 1.66 \\
\hline Total & 60 & 8.47 & 6 & 6 & 1.00 \\
\hline
\end{tabular}

Table 4. The analysis of risk factors for low outcome. * significant at $5 \%, * *$ significant at $1 \%$

\begin{tabular}{|l|c|c|c|c|}
\hline & Pearson Correlation & Rate of increment & t \\
\hline Age & 0.01 & 1.48 & 1.70 & 0.097 \\
\hline Cardiac sign & 0.14 & 0.15 & 0.22 & 0.830 \\
\hline $\begin{array}{l}\text { Respiratory } \\
\text { History }\end{array}$ & $0.38^{* *}$ & 2.09 & 1.24 & 0.222 \\
\hline BP systolic & $0.34^{* *}$ & 0.53 & 1.67 & 0.101 \\
\hline Pulse & $0.22^{*}$ & 0.66 & 1.58 & 0.122 \\
\hline Hb & $0.59^{* *}$ & 1.76 & 5.62 & $<0.001$ \\
\hline WBC & $0.27^{*}$ & 2.50 & 3.36 & 0.002 \\
\hline Urea & $0.45^{* *}$ & 5.54 & 6.63 & $<0.001$ \\
\hline Sodium & $0.44^{* *}$ & 1.81 & 2.44 & 0.019 \\
\hline Potassium & $0.32^{* *}$ & 1.30 & 2.25 & 0.030 \\
\hline ECG & 0.02 & 0.28 & 0.40 & 0.689 \\
\hline Multiple procedure & 0.04 & 0.37 & 0.26 & 0.794 \\
\hline Total blood loss & 0.16 & 0.87 & 1.28 & 0.206 \\
\hline Peritoneal soiling & 0.18 & 1.13 & 4.58 & $<0.001$ \\
\hline Malignancy & 0.06 & 1.41 & 0.82 & 0.414 \\
\hline Mode of surgery & $0.44^{* *}$ & 2.91 & 5.16 & $<0.001$ \\
\hline
\end{tabular}


most of these perforations are emergency conditions of the abdomen that require early recognition and timely surgical treatment. The main stay of treatment for bowel perforation is exploratory laparotomy. Peritonitis due to perforation of hollow viscous is most common surgical emergency in our part of world which is different from that found in western world. ${ }^{21}$

The treatment outcome whether in the form of mortality or morbidity is not only dependent on the performance of individual surgeon but also on the acute and chronic physiological status of the patient, severity of his current illness, nature and extent of surgical intervention and co-morbid conditions. The morbidity and mortality rates are misleading and inaccurate for surgical audit. For this purpose, different system of scoring were developed for risk prediction and adjusted mortality and morbidity. ${ }^{1-4}$ To overcome the shortcoming POSSUM, developed by Copland GP. et al, a risk adjusted scoring system for surgical audit PPOSSUM, a modification of POSSUM, has been proposed as a better scoring system as it better correlates with the observed mortality rate. ${ }^{7,8}$ But PPOSSUM has to be correlated to the general condition of the local population for it to be effective. $7,8,14,15,19,22$ This is especially true in patients in developing countries like ours where the general health of the population is poor, malnutrition is a common problem and presentation frequently delayed.19,20,22

In our study we assessed the validity of PPOSSUM in 60 patient who underwent emergency laparotomy by comparing the observed mortality rate with expected mortality rate. Six patients died (mortality rates of $10 \%$ ), the total crude mortality rate being $12 \%$. Similar study was done by Tekkis et al and obtained similar results (elective $=3.9 \%$, emergency $25 \%$ and overall mortality rate of $11.1 \%) .{ }^{15}$ However, on using P-POSSUM for MJSBH Vol 16 Issue 2 July-Dec 2017 expected mortality rate in our study it was also found to be six deaths. On analysis, this was found to be no statistically significant difference between the observed and expected mortality rates (Chi square $\mathrm{x} 2=1.523,4 \mathrm{df}, \mathrm{p}=0.823)$. An $\mathrm{O}: \mathrm{E}$ ratio of one was obtained in our case which is similar to one obtained by Yii $\mathrm{MK}$ and $\mathrm{Ng}$ KJ. et. al. evaluated POSSUM and P-POSSUM scoring systems for prediction of mortality rates among patients undergoing general surgery in a tertiary referral hospital in Malaysia $(\mathrm{O}: \mathrm{E}=1.28){ }^{20}$

Tekkis et al analysed mortality in patients undergoing gastrointestinal surgery using POSSUM and P-POSSUM scoring systems. A total of 505 consecutive patients undergoing major gastrointestinal surgeries were analysed. The observed mortality rate was 56 deaths, while the expected mortality rate using POSSUM was 108 deaths, which was found to be a significant over prediction $(\mathrm{x} 2$ test $=44.82,4$ d.f., $\mathrm{p}<0.001)$. Using P-POSSUM, the expected rate was 57 ( $\mathrm{x} 2$ test $=3.34,4$ d.f., $\mathrm{p}=0.51$ ). Comparison suggests PPOSSUM as the recommended scoring system for risk adjusted performance measurement $(\mathrm{O}: \mathrm{E}=$ 0.98). ${ }^{15}$ Similar results were found when Mohil R. et al. compared POSSUM and P-POSSUM for predicting the adverse outcome rate in patients undergoing emergency laparotomy. ${ }^{22}$ P-POSSUM was able to accurately predict the adverse outcome following emergency laparotomy in our study also.

In our study on analysing the risk factors we found positive rate of increment with all the risk factors studied but it was found to be statistically significant with respect to hemoglobin $(\mathrm{p}=0.001)$, WBC $(p=0.002)$, urea $(p=0.001)$, sodium $(p=$ $0.019)$, potassium $(\mathrm{p}=0.030)$, peritoneal soiling ( $\mathrm{p}$ $=0.001)$ and mode of surgery $(\mathrm{p}=0.001)$. Wound infection (48.3\%) was found to be the most common complication, followed by the chest infection $(26.7 \%)$. Similar results were obtained by 
Mohil et. al. ${ }^{22}$ (35\% and $20 \%$ respectively). Large number of individuals with gross peritoneal contamination after hollow viscous perforation leading to local contamination of the incision site may attribute to wound infections.

\section{CONCLUSION}

The present study suggests that P-POSSUM is an accurate scoring system for predicting postoperative adverse outcome among patients undergoing major general surgeries. The complications of wound infection and chest infection were a concern and require better care for their prevention following major general surgeries.
All the studied risk factors were found to have a positive rate of increment of deaths with higher scores. Hence adequate and prompt correction of these factors before surgery could decrease the mortality rate.

This study therefore validates P-POSSUM as a valid means of assessing adequacy of care provided to the patient to prevent the post-operative complications which can further lead to morbidity and mortality. Hence P-POSSUM can be used for surgical audit to assess and improve the quality of surgical care and result in better outcome to the patient preventing the anticipated complications in the emergency laparotomy cases.

\section{REFERENCES}

1. Copeland GP, Jones D, Wilcox A, Harris PL. Comparative vascular audit using the POSSUM scoring system. Annals of the Royal College of Surgeons of England. 1993;75(3):175-7. PMid: 8323212 PMCid: PMC2497876

2. Sagar PM, Hartley MN, Mancey-Jones B, Sedman PC, May J, Macfie J. Comparative audit of colorectal resection with the POSSUM scoring system. The British journal of surgery. 1994;81(10):1492-4.

DOI: https://doi.org/10.1002/bjs.1800811031 PMid:7820482

3. Jones HJ, de Cossart L. Risk scoring in surgical patients. The British journal of surgery. 1999;86(2): 149-57.

DOI: https://doi.org/10.1046/j.1365-2168.1999.01006.x PMid:10100780

4. Jones DR, Copeland GP, de Cossart L. Comparison of POSSUM with APACHE II for prediction of outcome from a surgical high-dependency unit. The British journal of surgery. 1992;79(12):1293-6.

DOI: https://doi.org/10.1002/bjs.1800791216 PMid:1486421

5. Copeland GP, Jones D, Walters M. POSSUM: a scoring system for surgical audit. The British journal of surgery. 1991;78(3):355-60.

DOI: https://doi.org/10.1002/bjs.1800780327 PMid:2021856

6. Copeland GP. Comparative audit: Fact versus fantasy. British Journal of Surgery. 1993;80(11):1424-5. DOI: https://doi.org/10.1002/bjs.1800801123 PMid:8252355

7. Whiteley MS, Prytherch DR, Higgins B, Weaver PC, Prout WG. An evaluation of the POSSUM surgical scoring system. The British journal of surgery. 1996;83(6):812-5.

DOI: https://doi.org/10.1002/bjs.1800830628 PMid:8696749 
8. Prytherch DR, Whiteley MS, Higgins B, Weaver PC, Prout WG, Powell SJ. POSSUM and Portsmouth POSSUM for predicting mortality. Physiological and Operative Severity Score for the enUmeration of Mortality and morbidity. The British journal of surgery. 1998;85(9):1217-20.

DOI: https://doi.org/10.1046/j.1365-2168.1998.00840.x PMid:9752863

9. Bennett-Guerrero E, Hyam JA, Shaefi S, Prytherch DR, Sutton GL, Weaver PC, et al. Comparison of PPOSSUM risk-adjusted mortality rates after surgery between patients in the USA and the UK. The British journal of surgery. 2003;90(12):1593-8.

DOI: https://doi.org/10.1002/bjs.4347 PMid:14648741

10. Wijesinghe LD, Mahmood T, Scott DJ, Berridge DC, Kent PJ, Kester RC. Comparison of POSSUM and the Portsmouth predictor equation for predicting death following vascular surgery. The British journal of surgery. 1998;85(2):209-12.

DOI: https://doi.org/10.1046/j.1365-2168.1998.00709.x PMid:9501818

11. Midwinter MJ, Tytherleigh M, Ashley S. Estimation of mortality and morbidity risk in vascular surgery using POSSUM and the Portsmouth predictor equation. The British journal of surgery. 1999;86(4):471-4. DOI: https://doi.org/10.1046/j.1365-2168.1999.01112.x PMid: 10215816

12. Treharne GD, Thompson MM, Whiteley MS, Bell PR. Physiological comparison of open and endovascular aneurysm repair. The British journal of surgery. 1999;86(6):760-4.

DOI: https://doi.org/10.1046/j.1365-2168.1999.01091.x PMid:10383575

13. Neary B, Whitman B, Foy C, Heather BP, Earnshaw JJ. Value of POSSUM physiology scoring to assess outcome after intra-arterial thrombolysis for acute leg ischaemia (short note). The British journal of surgery. 2001;88(10):1344-5.

DOI: https://doi.org/10.1046/j.0007-1323.2001.01914.x PMid:11578289

14. Sagar PM, Hartley MN, MacFie J, Taylor BA, Copeland GP. Comparison of individual surgeon's performance. Risk-adjusted analysis with POSSUM scoring system. Diseases of the colon and rectum. 1996;39(6):654-8.

DOI: https://doi.org/10.1007/BF02056945 PMid:8646952

15. Tekkis PP, Kocher HM, Bentley AJ, Cullen PT, South LM, Trotter GA, et al. Operative mortality rates among surgeons: comparison of POSSUM and p-POSSUM scoring systems in gastrointestinal surgery. Diseases of the colon and rectum. 2000;43(11):1528-32.

DOI: https://doi.org/10.1007/BF02236732 PMid:11089587

16. Tekkis PP, Kessaris N, Kocher HM, Poloniecki JD, Lyttle J, Windsor AC. Evaluation of POSSUM and P-POSSUM scoring systems in patients undergoing colorectal surgery. The British journal of surgery. 2003;90(3):340-5.

DOI: https://doi.org/10.1002/bjs.4037 PMid:12594670

17. Zafirellis KD, Fountoulakis A, Dolan K, Dexter SP, Martin IG, Sue-Ling HM. Evaluation of POSSUM in patients with oesophageal cancer undergoing resection. The British journal of surgery. 2002;89(9): 1150-5.

DOI: https://doi.org/10.1046/j.1365-2168.2002.02179.x PMid:12190681 
18. Lai F, Kwan TL, Yuen WC, Wai A, Siu YC, Shung E. Evaluation of various POSSUM models for predicting mortality in patients undergoing elective oesophagectomy for carcinoma. The British journal of surgery. 2007;94(9):1172-8.

DOI: https://doi.org/10.1002/bjs.5793 PMid:17520711

19. Tambyraja AL, Kumar S, Nixon SJ. POSSUM scoring for laparoscopic cholecystectomy in the elderly. ANZ journal of surgery. 2005;75(7):550-2.

DOI: https://doi.org/10.1111/j.1445-2197.2005.03428.x PMid:15972044

20. Yii MK, Ng KJ. Risk-adjusted surgical audit with the POSSUM scoring system in a developing country. Physiological and Operative Severity Score for the enUmeration of Mortality and morbidity. The British journal of surgery. 2002;89(1):110-3.

21. Jhobta RS, Attri AK, Kaushik R, Sharma R, Jhobta A. Spectrum of perforation peritonitis in India-review of 504 consecutive cases. World journal of Emergency surgery. 2006 Sep 5;1(1):26. https://doi.org/ $10.1186 / 1749-7922-1-26$

DOI: https://doi.org/10.1046/j.0007-1323.2001.01979.x PMid:11851674

22. Mohil RS, Bhatnagar D, Bahadur L, Rajneesh, Dev DK, Magan M. POSSUM and P-POSSUM for riskadjusted audit of patients undergoing emergency laparotomy. The British journal of surgery. 2004;91(4): 500-3.

DOI: https://doi.org/10.1002/bjs.4465 PMid:15048756 